Article

\title{
Luxury Products and Sustainability Issues from the Perspective of Young Italian Consumers
}

\author{
Tonino Pencarelli ${ }^{1}$, Viktória Ali Taha ${ }^{2, *}$, Veronika Škerháková ${ }^{2}$, Tomáš Valentiny $^{2}$ and \\ Richard Fedorko ${ }^{2}$ \\ 1 Faculty of Economics, University Urbino Carlo Bo, via Saffi 42, 61029 Urbino, Italy; \\ tonino.pencarelli@uniurb.it \\ 2 Faculty of Management, University of Prešov, Konštantínova 16, 08001 Prešov, Slovakia; \\ veronika.skerhakova@smail.unipo.sk (V.Š.); tomas.valentiny@smail.unipo.sk (T.V.); \\ richard.fedorko@unipo.sk (R.F.) \\ * Correspondence: viktoria.ali-taha@unipo.sk; Tel.: +421-905-162-111
}

Received: 4 November 2019; Accepted: 10 December 2019; Published: 27 December 2019

\begin{abstract}
The aim of this study is to understand the actual preferences, behaviors, and purchasing decisions of young consumers in the context of sustainability, with an emphasis on luxury products. The primary objective of the research is to determine the impact of 'sustainable tendencies' on stimulating the purchase of luxury goods by the Italian Generation $\mathrm{Z}$ and Generation $\mathrm{Y}$ populations. In addition to examining the intergenerational differences in perception of corporate social responsibility (CSR) and sustainable marketing, the study is aimed at investigating the potential intersection of the consumption of luxury products and the consumption of slow fashion. In particular, through an empirical analysis carried out on a sample of 1314 young consumers in Italy (representing the two generational cohorts), this research provides interesting results which demonstrate the importance of adopting differentiated CSR strategies which are attentive to sustainability based on the demographic characteristics of young consumers of luxury brands. Structural equation modeling is used to analyze and understand the structural relationships between variables. This study thus helps to fill the knowledge gap about the consumption orientation of the younger generations. The results of this study contribute to a growing body of literature on luxury brands and sustainability issues in marketing.
\end{abstract}

Keywords: consumer behavior; generations; luxury consumers; slow fashion; corporate social responsibility (CSR) and luxury

\section{Introduction}

An increasing number of studies have been devoted to exploring the relationship/compatibility between luxury and sustainability. Young luxury consumers have been increasingly interested in social and environmental issues and the sustainability of the luxury goods they buy; therefore, the challenge for luxury companies is to incorporate sustainability into their brand development. However, it is still not entirely clear to what extent luxury and sustainability can be harmonized and what the real opinions of luxury consumers on sustainability are. Scientific investigation of the perception of young generations on luxury and sustainable products is still in a nascent stage. After developing a conceptual framework of the issues related to sustainable luxury, this paper wishes to fill the knowledge gap of the consumption orientation of the young generations. In particular, a deep understanding of the perception of young luxury consumers on the social and environmental dimensions of sustainability is needed, as they represent the future evolution of the luxury market. 


\section{Literature Review}

Nueno and Quelch [1] (p. 177) reported that "Historically, the term "luxury" was applied to items that were both rare and scarce and available only to the elite few". The essence of luxury is a "symbolic desire (albeit often repressed) to belong to a superior class, which everyone will have chosen according to their dreams, because anything that can be a social signifier can become a luxury". Luxury products (i.e., products or services) are usually those which have the highest price and quality, providing the consumer with an outstanding experience or sense of prestige (e.g., watches, jewellery, high-specification interiors, high fashion, exclusive resorts, and top restaurants, as well as rare and enjoyable experiences) and evoke perceptions of rarity, privilege, and an exceptional life [2]. One of the main reason for purchasing and consuming luxury products is self-enhancement (status, success, and prestige), which mainly refers to the pursuit of self-interest and one's own relative success over others [3]. Luxury goods often serve as signs of membership to the affluent class and their public exposure should evoke both the envy and appreciation of the lower classes. Thus, they improve the self-image of their owners. The social and hedonic values encompassed in luxury goods are one of the most important reasons for which people buy and publicly expose them [4]. According to Veblen (1899, in [4]) the main reason for the consumption of luxury products is not to satisfy needs, but to display the luxury items publicly, hence signaling the material affluence of their owners. Leibenstein claimed that "consumers of luxury products are often charged with trying to impress others, with trying to be highly visible. The purchase of luxury goods would then not result from an intrinsic appreciation of the goods but rather from snob and bandwagon effects" [5] (p. 18). For luxury consumers, a luxury is more than a logo; it is an appreciation of fine work, fine craftsmanship, creativity, and the making of a legend [6].

\subsection{Luxury and Luxury Products}

Luxury products have, for a long time, been considered superfluous or targeted to a very small group of individuals, enabling them to differentiate from the crowd. However, at present, "the word "luxury" carries a much less negative connotation". Nevertheless, the idea that "luxury products are sophisticated, expensive, have a reasonably high quality, and bear a very strong and attractive brand name" persists in the mind of the consumer [7] (p. 2). According to Berry [8] (p. 4) "luxury might seem to imply exclusiveness" and "luxury goods are seemingly to be associated with expensiveness and rarity."

In generally, "luxury" is associated with the following notions: (1) perceived excellent quality: a luxury product should look better and should have a clear and generous warranty, sophisticated packaging, and a higher price; (2) very high price: the perception of high price could be established on the basis of the absolute value of the price or by comparison with non-luxury substitutes; (3) scarcity and uniqueness: these are closely associated with the previous two characteristics, supreme quality and high price-luxury products cannot be mass-produced because of their special components, uncommon nature of the skills essential to their manufacturing and delivery process, and the resulting higher price; (4) aesthetics and polysensuality: one of the aspects of luxury which involves strong aesthetic appeal-aesthetics are not only expected from the goods themselves, but also from the context in which they are presented and from the people who consume the goods; (5) hedonism: a luxury product should be pleasant to own and use and provide a personal sense of satisfaction (most consumers describe their consumption of luxury as a highly hedonic experience, which can affect all their senses); (6) ancestral heritage and personal history: in the consumer's mind, to be luxurious, products and services must have a long history and elaborate processes. In addition, consumption should respect tradition; (7) superfluousness or uselessness: luxury products are not considered to be necessary for survival; (8) exclusivity: a luxury product should be rare and slightly difficult to acquire; and (9) brand image: it should be unique, different, and strongly positioned [5,7]. The abovementioned notions could be considered the different dimensions of luxury. However, luxury is not static, it changes and 
evolves with the fulfillment of desires and inevitably related beliefs, which are subsequently filled "with further qualitative adjustments and improvements" [8] (p. 18).

Chevalier and Gutsatz [7] defined the criteria that different individuals use to distinguish one luxury product from another: (1) in terms of perception, the consumers decide what is and what is not a luxury object; (2) in terms of production, the manufacturers themselves decide whether they want their products to be part of the luxury world; and (3) in terms of social and individual behavior, a luxury product is described by sociologists as an item that makes its user stand out from crowd. Generally, there are four principal categories of luxury goods: (1) fashion (couture, ready-to-wear, and accessories), (2) perfumes and cosmetics, (3) wines and spirits, and (4) watches and jewellery. However, the offered luxury product categories have continued to expand [9].

Luxury brands have been "defined in terms of their excellent quality, high transaction value, distinctiveness, exclusivity and craftsmanship" [10] (p. 4). A luxury brand "is perceived to be the extreme end of the prestige-brand category", which consists of three types of prestigious brands: upmarket brands, premium brands, and luxury brands [11]. A luxury brand is a means of social distinction and social stratification, which "lies at the confluence between culture and social success". Money itself is not a measure of taste, it is only a measure of the wealth of the buyer; thus, money (more precisely, high prices) is not enough to define luxury goods [6] (p. 314).

Kapferer and Bastien [6] have emphasized that two main motives for luxury product purchasing - the consumer's pleasure (luxury for self) and the demonstration of success (luxury for others) - will affect the future of luxury brands; however, it should be noted that there are significant geographical differences in these motives, which depend on whether luxury goods are traditionally produced and consumed in the country or whether the consumption of luxury products is a relatively new phenomenon. In addition, consumers often buy luxury products as gifts. Despite differences in purchasing motivations, the brand is still the main vehicle for connecting with the consumer [12]. A brand may influence consumer perceptions of and attitudes toward it in several ways, including brand awareness, perceptions of image, and preference for the brand. A consumer will pay the high price of luxury, because a luxury product fulfils all their emotional, symbolic, and experiential needs [13]. The brand identity must be coherent and consistent with what the product represents and should bring additional value without betraying it [7] (p. 3)

Luxury brands are not launched; they are progressively built "by managing the allocation of resources in a very specific way" [6] (p. 313). They have set trends and "influenced the rest of the industry with their aesthetic value and innovative yet traditional way of business management". They apply innovative styles not only to products, but also to customer management, marketing mixes, customer services, retail strategies, and more [14] (p. 165). Koehn [13] listed three possible causes of luxury brand growth: (1) wealthy people purchasing more luxury products; (2) number of wealthy people increasing; or (3) middle and lower classes buying luxury brands. Probably the number of people who want to own luxury exceeds the number of people who have the economic means to do it regularly.

Traditional marketing tools-mass distribution, internet, and call centres-have been used to facilitate quick access to the product. However, these tools are not used for luxury products. Consumers of luxury products enjoy the luxury after passing through obstacles: financial, cultural (they have to know how to appreciate the product, wear it, and consume it), logistical (finding the shops) and time (waiting for production and delivery of luxury products, which are associated with longer waiting periods). Therefore, for luxury products, a built-in time factor (the time necessary for searching, waiting, and longing) must also be taken into account [6].

\subsection{Sustainable and Slow Fashion Concepts}

It has been proven that fashion has a negative environmental impact. According to Chow and $\mathrm{Li}$ [15], the fashion industry is the second-largest polluting industry. In recent years, many fashion companies have started to incorporate the factor in sustainability into their business model. 
Fashion companies have begun to think about whether (the highly profitable) affordable and trendy fashion could be in balance with ethical issues such as environmental sustainability. A number of fashion companies have been launching programs to collect used clothes from customers, where the collected items are subsequently resold or donated for second-hand stores or recycled into fibres or fuels, thus reducing waste and pollution, and preserving the environment [15]. However, many authors have been sceptical of the sustainability efforts of the major fashion retailers, believing that "although fashion producers and retailers offer one-off sustainable options, they still rely on hyper-consumption and low prices to meet their business goals" (Fletcher, 2010, in [16] (p. 6)).

Sustainable fashion is an alternative trend against fast fashion [17]. It "encompasses a variety of terms such as organic, green, fair trade, sustainable, slow, eco and so forth, each attempting to highlight or correct a variety of perceived wrongs in the fashion industry" (Cervellon et al., 2010, in [18]). The concept of sustainable fashion refers to a range of activities aimed at the correction of a "variety of perceived wrongs in the fashion industry" (e.g., animal cruelty, environmental damage, and worker exploitation) (Lundblad \& Davies, 2015, in [19]). Sustainable fashion (also known as "eco fashion") is a part of a growing design, manufacturing, and use philosophy and trend toward maintainability, the goal of which is to create a system which is supportable indefinitely, in terms of human impact on the environment and social responsibility. This definition includes three focal points: the attitudes, beliefs, plans, and behaviours of designers, manufacturers, and consumers regarding sustainable fashion issues [17].

Sustainable products are products that provide environmental, societal, and economic benefits while protecting public health, welfare, and the environment over their full commercial cycle (from the extraction of raw materials to final disposition), providing for the needs of future generations [20](p. 2). Multiple ways to define and measure the sustainability of a product have been proposed. As products have many dimensions and attributes and they are manufactured and delivered in many different ways, products can fulfil sustainability criteria in many ways. Kevin Brady [21] listed some of the ways to make a product sustainable: (1) when designing the product, the emphasis should be on material selection, processes used, logistics optimization, and packaging; (2) throughout the product supply chain, responsible labor, community and worker health, and safety practices should be ensured; and (3) the products should have a low carbon footprint, contain recycled content, and be produced considering water and/or energy efficiency. Jawahir et al. [20] appointed the three most-common criteria for sustainable product development: (1) minimization of the material and energy resources needed to satisfy the product function and consumer demand; (2) maximizing the use of resources expended; and (c) minimizing/eliminating the adverse effects of waste and emissions. A special category of sustainable products is green, environmentally friendly products, which reduce natural resource usage, prevent waste generation, avoid toxic materials, and/or reduce hazardous impact on environment throughout the whole production life cycle (Tsai, 2010, in [22]). Pui-Yan Ho and Choi's study [23] revealed that a majority of the surveyed organizations believed that 'green' efforts would strongly impact their reputation and brand. Increased brand equity and reputation for CSR enable organizations to maintain their current customer loyalty and attract new customers.

In the context of the above discussion, the development of sustainable products and business practices are a form of reaction of fashion companies to criticism of their unsustainable conduct, negatively impacting environmental quality and human well-being by producing carbon emissions, poor labour conditions, excessive waste, and chemical usage [19]. A growing consumer concern about sustainability issues has been reflected in a willingness to pay higher prices for products and services provided by companies involved in social and environmental activities (Johnstone \& Tan, 2015, in [19]). Consumers have been shown to care more about sustainability and sustainable fashion, and it seems that sustainable fashion has become as much about the product itself as the shopper's attitude toward it [24]. This is one reason why there has been increased interest and attention from academics and practitioners in ethics, environmental concerns, and sustainability issues relating to affordable, trend-sensitive, and fast fashion (Chan \& Wong, 2012; Joy et al., 2012; Sun, Kim, \& 
Kim, 2014, in [19]), in order to determine how fashion consumers form their judgments and make purchasing decisions about eco-friendly and/or sustainable products. However, despite a growing interest in sustainable fashion, consumers also require that sustainable fashion meets aesthetic and style requirements. Beard (2008, in [18]) has shown that price, quality, and appearance of clothing are still more important than ethics when making purchasing decisions; that is, clothing must not only be sustainable, but also meet the consumer's aesthetic needs. Thus, the mere fact that a product meets a sustainability criterion does not seem to be a strong enough incentive for the consumer to favor it.

Han, Seo, and Ko [19] pointed out that "consumers are in constant state of psychological imbalance, an attitude-behavior gap, between their sustainability concerns and their own sustainable fashion products consumption". When explaining the relationship between general attitudes toward sustainability and ethical issues (on one hand) and buying behaviour (on the other hand), many authors have referred to Heider's (1958) balance theory (in [19]), which helps to understand the sustainable fashion paradox and sustainable fashion product consumption behaviours. For example, Pui-Yan Ho and Choi [23] found that many consumers were willing to pay a higher price for eco-friendly products from environmentally-friendly retailers and/or produced by environmentally-friendly producers. Han et al. [19] pointed out that recent studies have revealed that consumers hesitate to adopt sustainable fashion. Moreover, there is an inconsistency/imbalance between consumer pro-sustainability attitudes and their sustainable fashion product consumption behaviours: although consumers are concerned about sustainability and expect fashion companies to show a social commitment, they do not demonstrate sustainable behavior when consuming fashion products (the so-called sustainable fashion paradox).

Cline (2012, in [16]) considered slow fashion to have arisen in opposition to fast fashion, but Fletcher (2010, in [25]) believed that slow and fast fashions represent different, but not opposite, attitudes, business processes, frameworks, and values. The purpose is to offer more sustainable and ethical ways of being fashionable (Clark, 2008, in [16]). Kate Fletcher [26] (pp. 260, 262) argued that, in the last ten years, fashion has often been associated with the words 'fast' and 'slow', as related to "a wide range of practices that are either more or less large-scale, logistics-dominated, economic growth-focused, ethical or ecological". The 'slow' refers to durable products, traditional production techniques, or season-less design concepts. The author also argued that slow fashion "is wheeled in to offer apparent legitimacy to existing products and business models, conferring upon them a sense of ethics and resourcefulness". Within slow fashion, the production, manufacturing, and final product should be sustainable; made of durable, recycled, or organic materials; and have timeless designs (i.e., both stylish and wearable over multiple seasons). The problem is that slow fashion products are usually more expensive than fast fashion ones, which discourages many consumers from adopting them [16].

Increased interest in the slow fashion concept has been related to an increased awareness of sustainability issues and concern about the negative environmental and human impact of the fashion industry [27]. It is associated with fair working conditions, sustainable business models, organic and environmentally friendly materials, certifications, and traceability (Henninger et al., 2016, in [27]). There have been evident changes in consumer behaviors regarding Slow Fashion: consumers have better awareness and think twice before they buy [25]. According to Cavender [28] (p. 30), "the emergence of sustainable fashion movements (e.g., slow fashion, conscious consumption) indicates that society as a whole is beginning to question the consumption-oriented dominant social paradigm, signaling an impending shift toward more sustainable consumption and increased commitment to sustainability initiatives by corporations". However, despite growing consumer awareness and concern about the slow fashion concept, there has not been an evident correlation to their sustainable behaviours in consumption (Kong et al., 2016, in [27]). Similarly, Goworek et al. (2012, in [16]) pointed out that the sustainable behaviour of consumers depends significantly more on their habits than on their knowledge of sustainable business practices. Hence, we hypothesize that: 
Hypothesis 1 (H1). Sustainable consumer behavior has a significant positive impact on slow fashion consumer behavior.

Hypothesis 2 (H2). Sustainable consumer behavior has a significant positive impact on sustainable consumer habits.

\subsection{Social Media, Luxury Brands, and Sustainable Marketing}

Social media plays a key role in a luxury brand's success. In order to survive, luxury brands have turned toward marketing communication by social media, which represents "the two-way communication platforms that allow users to interact with each other online to share information and opinions". The popularity of social media has also been evidenced by the fact that almost all luxury fashion brands use social media websites (e.g., Twitter or Facebook) [14] (p. 164). Social media has changed the way in which the branding content is created, distributed, and consumed, transferring the power to shape brand images from marketers to consumer's online connections and content [29]. Social media includes five features: entertainment, customization, interaction, word of mouth, and trend (trendiness) [14].

What is the dilemma and resilience of luxury brands using social media? For a long time, luxury brands were resistant to social media, because they believed that the technology was a threat and "works against the firms' desire to control their own brands". Moreover, the luxury market did not believe in websites and e-commerce potential to attract customers [14] (p. 166). Jin [30] pointed out that luxury brands sell their products mainly in offline stores as they pursue uniqueness and exclusivity through strictly controlled distribution. For that reason, luxury brands face the dilemma of whether to keep up with the trend of social media or maintain their brand integrity, uniqueness, and exclusivity through high quality, premium pricing, and controlled distribution.

Many studies have focused on the use of social media by luxury brands in marketing. Schwedt et al. (2012, in [31]) investigated two types of customer populations-French and Italian (representatives of historically well-established traditional luxury markets with consumers with refined fashion tastes and preferences) and Chinese and Indian (representatives of rapidly growing luxury markets with consumers who have only recently gained access to these kinds of goods) — for five globally renowned luxury brands. Their study revealed that social media marketing had significant positive effects on brand equity and consumer responses, including on brand loyalty, preference, and willingness to pay a premium price.

According to Deloitte, the future of the global luxury market has been affected by the digital revolution, as well as by technology, the growing global middle class, and the influence of Millennials and Generation Z. "Luxury brands usage of social media as a part of their marketing strategy. To stimulate interest among Millennials and Generation Z, luxury brands are increasingly using social media platforms to engage with young consumers, while trying to keep their brand value intact. The future success of luxury brands depends on how well they will be able to communicate and market their goods to the new generations of tech-savvy buyers" [32] (p. 9). A majority of luxury brands have their own distinct social media strategies and many of them have also developed relationships with influencers and niche bloggers, who advocate the brand within interested communities [32].

Based on the above, we believe that consumer perception of the importance of implementing sustainable marketing strategies will affect slow consumer behavior, as well as sustainable consumer habits. Formally, we hypothesize that:

Hypothesis 3 (H3). Increasing the value of the latent variable of sustainable marketing (perceived importance of applying sustainable marketing strategies) has an impact on increasing sustainable consumer habits.

Hypothesis 4 (H4). Increasing the value of the latent variable of sustainable marketing (perceived importance of applying sustainable marketing strategies) has an impact on slow fashion consumer behavior. 


\subsection{Luxury Brands and Their Pro-environmental and Pro-social Behaviour}

Carrigan et al. [33] stated that, compared to cheap fashion (usually disposable fashion), luxury fashion brands represent a more sustainable type of fashion; this is because luxury brands usually manufacture small quantities of products (in order to stay exclusive) with high quality and long lifecycles. Thus, they waste significantly fewer resources than mass-market brands and, so, luxury goods can be regarded as inherently sustainable (Amatulli et al., 2017, in [34]).

Consumers have become better informed, more selective, and have shown increased concern about the environmental and social consequences of their consumption. This increased consumer awareness has led to a greater involvement of organizations in corporate social responsibility (CSR) activities. According to Torelli et al. (2012), "consumer perceptions of CSR of brands affect their willingness to buy certain brands which, in turn, affects firms' decisions to invest in CSR" [3] (p. 1366). Corporate social responsibility has been defined as "an organization's endeavours and standing in regard to its societal or stakeholder obligations to increase its positive impact and minimize its negative impact on society" (Brown \& Dacin, 1997, in [35]). According to Bednárová et al. [36], the essence of CSR is to find and continually maintain a balance between a company's economic efficiency, social engagement, and environmental responsibility. Its essence is the belief that, in addition to governments, businesses and companies should also contribute and take responsibility for the well-being of society, environmental protection, sustainable development, and the rational use of non-renewable resources.

Maon et al. (2009, in [33]) argued that corporate social responsibility has changed from an ideology to reality and that it represents an important part of current business practices. Therefore, it is dangerous for companies to ignore social responsibility pressures. CSR, as a tool, seems to have become an essential value for companies. Employee involvement, environmental concern, reducing waste, and optimizing energy consumption and waste cycles represent the areas of greatest commitment declared by companies engaged in CSR [37]. Sojka and Tej [38] emphasized that, in general, there are many pros and cons to CSR. However, there are no known studies which have revealed that companies behaving pro-socially and pro-environmentally are less efficient; on the contrary, there have been many studies which confirmed that CSR is beneficial for companies in the long term and that it represents the only possible behaviour, at present, in terms of sustainable development. According to Shnayder et al. [39], the benefits of CSR are multiple and are manifested in several areas at the same time; for example, quality assurance and maintenance have the two potential benefits of consumer satisfaction (people) and reputation (profit), and reducing energy use could have both environmental (planet) and cost-reducing (profit) effects.

An interesting look at CSR activities has been offered by Joo, Miller, and Fink [35], who investigated the influence on consumer perceptions of the authenticity of the CSR activities done by organizations. They examined seven dimensions of CSR authenticity: (1) community link (the degree to which stakeholders perceive CSR initiatives to be connected to their communities), (2) reliability (the degree to which stakeholders perceive that the CSR program actually does what it promises to do), (3) congruence (the degree to which stakeholders perceive an alignment between an organization's CSR efforts and the vital core of its own business), (4) commitment (the degree to which stakeholders perceive the organization as dedicated or steadfast in its CSR initiatives, as opposed to adjusting initiatives to meet current trends), (5) benevolence (the degree to which stakeholders perceive CSR initiatives as altruistic), (6) transparency (the degree to which stakeholders perceive CSR decisions, practices, outcomes, and so on to be open and available to public evaluation), and (7) broad impact (the degree to which the initiative benefits numerous recipients). Their research found positive effects of authenticity on a variety of consumer outcomes.

As highlighted by Amatulli et al. [34] (p. 278), “CSR can be leveraged to enhance consumers' perception of luxury brands"; thus, CSR has become one of the key pillars of luxury market strategies. Authors have distinguished external and internal CSR activities: initiatives within the economic and ethical CSR dimensions (i.e., reducing production costs and improving working conditions) represent 
internal CSR activities, as they are less visible and harder to perceive by consumers, whereas the legal and philanthropic CSR dimensions (e.g., including required information on product packaging and financially supporting local community projects) belong to external CSR activities [34]. Carrigan, Moraes, and McEachern [33] believed that luxury fashion businesses should deal with CSR and set sustainability as a corporate goal, as it will allow them to naturalize and develop long-term core competencies which will be hard to imitate by competitors. Whereas fashion will probably be directed towards a more responsible future, it is crucial for the international luxury fashion industry to embrace responsible values in their sourcing, manufacture, and distribution of their products and services (Laudal, 2010, in [33]), concentrating on those consumers that form 'part of an affluent, global elite that is increasingly well-educated and concerned about social and environmental issues' (Bendell \& Kleanthous, 2007; Reuters, 2009; The Cooperative Bank, 2010, in [33]). As consumption has historically evolved from a private, needs-oriented activity to a socially-construed, desire-sustaining activity (Bauman, 2004, in [33]), the influential position of the luxury fashion consumers who embrace socially-responsible fashion brands have the potential to influence, normalize, and lead the diffusion of desirable, pro-environmental, and pro-social behaviours [33]. As CSR seems to be an important factor in the decision-making of luxury consumers, we hypothesize that:

Hypothesis 5 (H5). The perception of using and applying CSR activities (by the brand) has a significant positive effect on increasing luxury goods purchasing.

Hypothesis 6 (H6). The perception of using and applying CSR activities (by the brand) has a significant positive effect on slow fashion consumer behavior.

However, based on the conviction that hedonism, excess, and ostentation (which are associated with luxury) are in contrast to sobriety, moderation, and ethics (which are the basis of CSR activities), some authors have proposed that CSR is not an important factor in the decision-making of luxury consumers, or even that CSR could worsen consumer perception of the quality of luxury goods [34]. Moreover, consumers sometimes perceive CSR activities negatively; particularly if the brands are involved in CSR activities mainly for selfish and acquisitive reasons (e.g., to have better consumer evaluations) and have no genuine and sincere interest in contributing to social welfare (Alcañiz et al., 2010; Chernev and Blair, 2015, in [3]).

Opinions on the attitudes of luxury fashion consumers towards CSR are different: some authors have argued that, given that "luxury fashion consumers are already willing to pay high prices, it is unlikely that any reasonable 'eco' or 'social' mark-up on their favourite luxury brands will act as a purchase dissuader" [33] (p. 26). Other authors have referred to self-enhancement (which is related to the notion of status) as the driving force for purchasing luxury products: self-enhancing consumers are less engaged in ethical behavior (e.g., they would prefer to buy a luxurious, but polluting, car than a small, less polluting, electric car) [3].

A number of studies have dealt with the question of whether luxury fashion can be sustainable, or how luxury and sustainability can converge. To make luxury fashion more sustainable, Godart and Seong [40] suggested three scenarios: (1) institutional change through slow luxury fashion (e.g., modifying the current fast trend cycles or seasons to slower ones), (2) innovative luxury fashion (e.g., using materials that have a lower impact on the environment, reduce waste at each step of the production process, and/or increase recycling of discarded clothes), (3) upgrading luxury fashion through regulation (i.e., regulations of the state or the industry). Elisa Arrigo [41] emphasized that luxury goods are inherently sustainable: their rarity, beauty, and especially durability (some luxury products are a form of investment, which are handed down from generation to generation due to the durable quality of their materials) form a basis for sustainable development. Additionally, in the case of crafted, handmade, and rare savoir faire production, companies invest in sustainable programs focused on employee training or building artisan schools in order to preserve luxury artisanship skills.

The literature review leads us to hypothesize the following: 
Hypothesis 7 (H7). Increasing the level of sustainable consumer habits of the population has a significant positive impact on increasing the luxury goods purchasing.

Hypothesis 8 (H8). Increasing the level of sustainable consumer habits of the population has a significant positive impact on slow fashion consumer behavior.

Hypothesis 9 (H9). There is a statistically significant positive covariance between CSR application and sustainable consumer habits.

Hypothesis 10 (H10). There is a statistically significant positive covariance between slow fashion consumer behavior and the latent variable defined as luxury good purchasing.

\subsection{Two Generational Cohorts and Their Perceptions of CSR}

Generation Y (the so-called 'Millennials'), born between 1980 and the mid-1990s, represent a huge consumer segment with growing purchasing power. Millennials represent $24 \%$ of the world's population: in Italy, there are 8.03 million, divided fairly evenly between males (50.5\%) and females (49.5\%) [42]. Millennials, who represent about half of the consumers, pay attention to CSR and are willing to pay more for sustainable products. According to Sullivan [43], the difference between Millennials and older generations of consumers lies in the fact that they are three times as likely as Generation $\mathrm{X}$ and 12 times as likely as Baby Boomers to respond favourably to sustainability actions. Members of Generation $Y$ have also been called Digital Natives, as they were the first generation to have spent their entire lives in the digital environment: information technology profoundly affects how they live and work [44]. They are digital, global, and hyper-connected: a vast majority of them $(97 \%)$ have at least one personal profile on a social network.

Generation Y consumers have benefited from the increased availability of customized products and personalized services [44], which has been reflected, among other things, in that they 'want it all' and 'want it now' [45]. They are very good at recognizing an advertising message, are able to distinguish authentic content from a promotional one and require authenticity. They want better and more innovative products and want them as quickly and conveniently as possible. CSR activities matter to this 'always connected' generation. A recent Nielsen study revealed that, for $85 \%$ of Millennials, it was extremely or very important that companies implement programs to improve the environment; furthermore, $75 \%$ declared that they definitely or probably would change their purchasing habits to reduce their impact on the environment. Millennials are particularly interested in charitable giving and partnerships, community activity and volunteering, fair-trade programs, environmental policies, and positive labor policies (e.g., anti-discrimination and anti-harassment practices) [46]. Studies have shown that millennial consumers are willing to support different social and environmental initiatives and their willingness to support the corporate social responsibility initiatives of food companies are affected by both trust and loyalty.

Generation Z (also called the 'iGeneration' or 'Post-Millennials'), born between 1995 and 2010, is an extremely pragmatic generation, have been born at a time of profound global and ideological crisis. Generation $\mathrm{Z}$ seems to be more sensitive, compared to previous ones, to environmental and social causes and is more engaged in voluntary work. For that reason, they prefer brands that are sensitive and actively involved in environmental problems and social issues (not those which have an excellent CSR program on paper, but those which make the world a better place) [47]. Another characteristic of Generation $\mathrm{Z}$ is the presence of a strong spirit of entrepreneurship and initiative. Research has showed that $72 \%$ of current high school students plan to run their own business in the coming years, while $76 \%$ would like their hobby to become a job. According to Fortune, the Millennials are waiting to be discovered, while Generation $\mathrm{Z}$ is ready to work hard to succeed [48].

Sharon Uche [49] examined the attitudes and perceptions of Generation $Z$ regarding a brand or a brand's CSR and found that Generation $Z$ consumers have more trusting relationships with 
brands who communicate their CSR involvement. Additionally, the research of Arıker and Toksoy [50] showed that the attitudes of Generation $Z$ toward the implementation of CSR activities by companies are positive. Generation $\mathrm{Z}$ consumers have no strong intention to purchase CSR related products. For them, the implementation of CSR activities is not sufficient incentive for purchasing; generation $Z$ consumers intend to purchase products only if the preconditions of price and quality are satisfied.

\section{Materials and Methods}

The primary data were collected through a survey, in the form of self-coined and self-administered questionnaires. The initial items/questions were focused on the socio-demographic characteristics of respondents. Despite a number of studies on sustainable and slow fashion, unambiguous characteristics of the consumers of sustainable and slow fashion are absent. Regarding socio-demographic characteristics, Franzen and Vogl [51] pondered what socio-demographic characteristics were linked to an individual's environmental concern and found that these characteristics included age, education, sex, and income. Furthermore, some basic value orientations, particularly Inglehart's post-materialism index (Inglehart, 1990, 1995, 1997, in [51]) and levels of trust (Meyer \& Liebe, 2010, in [51]) have been closely associated with environmental attitudes. According to Milfont and Markowitz [52], sustainable consumption and pro-environmental attitudes are influenced by individual and contextual factors. As for individual factors, income, education level, general trust in other individuals, and post-materialist values (e.g., support for greater public participation in government decisions and protecting freedom of speech) have been shown to affect pro-environmental attitudes and eco-friendly behavior. For example, older consumers, men, and political conservatives tend to report weaker environmental attitudes. For that reason, basic socio-demographic characteristics of respondents, such as gender, age, and educational attainment (the highest degree or level of school completed), as well as items regarding post-materialism, were included in the questionnaire. In addition to these items, we also surveyed the respondent's residence (urban/rural), the number of household members, and political orientation (which have been shown not to be statistically significant). Our study was focused on examining the differences between respondents, in terms of socio-demographic characteristics such as age (generation), gender, or educational attainment.

The core of the questionnaire consisted of factual items/questions (in the form of statements) focused on sustainable consumer habits, slow fashion consumer behavior, sustainable marketing, luxury goods, and CSR activities (made by the brands). Within the slow fashion consumer behavior (SF), we investigated, for example, whether respondents were willing to accept a higher price tag while buying fashion products, whether ethical and CSR activities of brands affected their buying decisions, whether they preferred to buy clothes made of premium quality materials, whether they were willing to pay a higher price for clothes made from local sources, whether they preferred quality of clothing instead of quantity, whether they preferred fashion brands (companies) supporting the local community, and so on. Another group of questions was related to the environmental (Env) and social (Soc) activities of brands (both within CSR). For example, respondents were asked how important it was for them that the brand they buy and wear: minimizes material and energy resources, eliminates excessive environmental pollution, uses recycled materials in the manufacture of products, purchases the materials needed to produce from naturally renewable sources, ensures decent working conditions for its employees, ensures a decent financial remuneration for its employees, supports gender equality, supports the maintenance and restoration of cultural heritage, and so on. We also explored buying preferences and behaviours of consumers, covering a range of sustainability issues such as: buying used clothing from second-hand stores, buying clothing in vintage stores, performing waste separation, living with a zero-waste philosophy, eating organic products, buying clothing made from organic or recycled materials, and so on, which together formed a latent variable of sustainable consumer habits (SCH). Items relating to luxury goods (LG) were focused on the frequency of their purchase, kind of goods purchased, their attributes, and so on. The last group of questions concerned the respondent's views on sustainable activities of the companies and their promotion, which we 
named 'sustainable marketing' (SM). Examples of items within this group of questions were: "Luxury brands have to be sustainable", "Luxury brands should use social media to promote their sustainability and CSR activities", "Promotion of sustainability and CSR activities would have an effect on my buying decisions", "The promotion of sustainability and CSR activities improve the image of the brand", and so on. Table 1 summarizes all variables and items.

Table 1. Variables and items.

\begin{tabular}{|c|c|}
\hline Variable & Item \\
\hline & Socio-demographic characteristics \\
\hline Q1 & Gender \\
\hline Q2 & Age \\
\hline Q3 & Educational attainment (the highest degree or level of school completed) \\
\hline$\widehat{Q} 4$ & Residence \\
\hline Q5 & Region \\
\hline Q6 & Number of persons living in your household \\
\hline Q7 & Your disposable income for your monthly purchases \\
\hline \multirow[t]{2}{*}{$\mathrm{Q} 8$} & Your political orientation \\
\hline & Sustainable consumer habits \\
\hline Q9.1 & I usually buy used clothing from second-hand stores. \\
\hline Q9.2 & I regularly buy clothing in vintage stores. \\
\hline Q9.3 & I do waste separation. \\
\hline Q9.4 & I live with a zero-waste philosophy. \\
\hline Q9.5 & It is important for me to eat organic products. \\
\hline Q9.6 & I prefer to buy clothing with a timeless design. \\
\hline Q9.7 & I prefer to buy clothing made from organic materials. \\
\hline Q9.8 & I prefer to buy clothing made from recycled materials. \\
\hline Q9.9 & I think that studying sustainability and CSR helped me to understand the importance of it. \\
\hline Q9.10 & I think that studying sustainability and CSR changed my consumers behavior. \\
\hline Q9.11 & $\begin{array}{l}\text { I think that studying sustainability and CSR will help me in my future career/work life. } \\
\text { Slow fashion consumer behavior }\end{array}$ \\
\hline Q10.1 & I am willing to accept a higher price tag while buying fashion products. \\
\hline Q10.2 & I am interested in ethical and CSR activities of brands I am buying. \\
\hline Q10.3 & Ethical and CSR activities of the brands have impact on my buying decision. \\
\hline Q10.4 & I am interested in transparent communication of the brand. \\
\hline Q10.5 & I buy clothes made from premium quality materials. \\
\hline Q10.6 & $\begin{array}{l}\text { It is important for me the brand (company) to inform me about the origin of the materials used for } \\
\text { production. }\end{array}$ \\
\hline Q10.7 & I am willing to pay a higher price for clothes made from local sources. \\
\hline Q10.8 & I am willing to pay a higher price for clothes from local (small) designers. \\
\hline Q10.9 & I am interested in individualistic and unique clothes made of recycled materials and textiles. \\
\hline Q10.10 & It is important for me the brand (company) to guarantee a fair profit to the producers. \\
\hline Q10.11 & Personalized service is important for me while shopping. \\
\hline Q10.12 & I think slow fashion is a competitor of fast fashion. \\
\hline Q10.13 & I prefer quality of clothing instead of quantity. \\
\hline Q10.14 & It is important for me the fashion brand (company) to support local community. \\
\hline Q10.15 & It is important for me my fashion consumer behavior to be holistic. \\
\hline Q10.16 & I do not often follow quickly changing fashion trends-I have my own style. \\
\hline \multirow[t]{3}{*}{ Q10.17 } & If slow fashion retailer would be certified, I would rather buy its products than fast fashion. \\
\hline & Perception of CSR (importance)—Environmental \\
\hline & For me it is important that the brand I buy and wear: \\
\hline Q11.1 & Minimizes the material and energy resources necessary to achieve product functionality \\
\hline Q11.2 & Eliminates excessive environmental pollution (emissions) in the production of products \\
\hline Q11.3 & Eliminates the use of genuine leather and animal parts during production \\
\hline
\end{tabular}


Table 1. Cont.

\begin{tabular}{|c|c|}
\hline Variable & Item \\
\hline Q11.4 & Maximizes the usability of the resources spent on production \\
\hline Q11.5 & Purchases the materials needed to produce from naturally renewable sources \\
\hline Q11.6 & Uses recycled materials in the manufacture of products \\
\hline Q11.7 & Uses recyclable materials in the manufacture of its products. \\
\hline Q11.8 & Manufactures its products from natural raw materials \\
\hline Q11.9 & Invests part of its profits in the innovation of technology needed for organic production \\
\hline \multirow[t]{3}{*}{ Q11.10 } & Helps the communities where it produces its products as compensation for environmental pollution \\
\hline & Perception of CSR (importance)-Social \\
\hline & For me it is important that the brand I buy and wear: \\
\hline Q11.11 & Ensures decent working conditions for its employees and respect their value \\
\hline Q11.12 & Ensures well-being to its employees \\
\hline Q11.13 & Ensures a decent financial remuneration for its employees \\
\hline Q11.14 & Supports gender equality \\
\hline Q11.15 & Gives its employees the opportunity for continuous education \\
\hline Q11.16 & Gives jobs also to disadvantaged (disabled) people \\
\hline Q11.17 & Offers key positions to long-term employees \\
\hline Q11.18 & Gives transparent information to their stakeholders and customers \\
\hline Q11.19 & Supports small local craftsmen \\
\hline Q11.20 & Supports the maintenance and restoration of cultural heritage \\
\hline Q11.21 & Is active in charity/have their own foundation \\
\hline \multirow[t]{2}{*}{ Q11.22 } & Regularly allocates part of its profits for charity. \\
\hline & Luxury goods purchasing \\
\hline \multirow[t]{2}{*}{ Q12 } & The frequency of buying luxury products \\
\hline & Types of luxury products purchased: \\
\hline Q13.1 & Clothing and footwear \\
\hline Q13.2 & Bags and accessories \\
\hline Q13.3 & Cosmetics and fragrances \\
\hline \multirow[t]{2}{*}{ Q13.4 } & Jewelry and watches \\
\hline & The highest price you are willing to pay for a luxury product: \\
\hline Q14.1 & Clothing and footwear \\
\hline Q14.2 & Bags and accessories \\
\hline Q14.3 & Cosmetics and fragrances \\
\hline \multirow[t]{2}{*}{ Q14.4 } & Jewelry and watches \\
\hline & I buy luxury products because of these features/ attributes: \\
\hline Q15.1 & Its added value \\
\hline Q15.2 & Design and beauty \\
\hline Q15.3 & Craftsmanship \\
\hline Q15.4 & Exclusivity \\
\hline Q15.5 & Quality materials \\
\hline Q15.6 & Uniqueness \\
\hline Q15.7 & Famous brand \\
\hline Q15.8 & High Price \\
\hline Q15.9 & Personalization of the product \\
\hline Q15.10 & "Made in Italy" designation \\
\hline Q15.11 & Fulfillment of my expectations \\
\hline Q15.12 & My own satisfaction \\
\hline Q15.13 & Reflection of my social status \\
\hline Q15.14 & It is a good gift for my relatives. \\
\hline Q16 & The frequency of following luxury brands profiles on social networks \\
\hline Q17.1 & Luxury brands have to be sustainable. \\
\hline $\mathrm{Q} 17.2$ & Luxury brands should use social media to promote their sustainability and CSR activities. \\
\hline Q17.3 & The promotion of sustainability and CSR activities would have an effect on my buying decisions. \\
\hline
\end{tabular}


Table 1. Cont.

\begin{tabular}{ll}
\hline Variable & \multicolumn{1}{c}{ Item } \\
\hline Q17.4 & I think that the promotion of sustainability and CSR activities improve the image of the brand. \\
Q17.5 & I think that influencers should promote sustainable fashion brands. \\
Q17.6 & I think that influencers should collaborate with luxury brands that apply CSR activities. \\
Q18 & Items regarding postmaterialism \\
\hline
\end{tabular}

The data collection took place in September 2019. Respondents indicated their level of agreement/disagreement on a five-point Likert scale, ranging from strongly agree to strongly disagree. The research sample consisted of young consumers in Italy, from all Italian regions in a balanced proportion to ensure the relevance and representativeness of the research sample. Respondents were restricted to consumers who were members of the two generations examined: Generations Y and Z. Of the total of 1314 respondents, 641 respondents were members of generation $Y$ and 672 were members of Generation Z. Among the respondents, 607 (46\%) were women and 707 (54\%) were men.

The primary objective of this study was to determine the impact of 'sustainable tendencies' on stimulating luxury goods purchasing and on the slow fashion consumer behavior of Italian Generation $\mathrm{Z}$ and Generation $Y$ members. In our study, 'sustainable consumer habits', the preference of purchasing from organizations applying corporate social responsibility or sustainable marketing are considered to be 'sustainable tendencies'. We also investigated the link between slow fashion and luxury goods; more precisely, whether the surveyed consumers perceived slow fashion as a part of the luxury goods segment. However, due to the significant differences within the examined generations, we will analyze them separately, which will enable us to identify the primary differences within the given issue. The formulated research hypotheses were defined in general, but all of them were evaluated separately for both generations.

The relationships and patterns between the basic concepts of the issue examined were the basis for the construction of the structural model represented by the following set of equations:

$$
\begin{gathered}
L G_{i} \sim f\left(Q 12_{i}, Q 13.1_{i}, \ldots, Q 13.4_{i}, Q 14.1_{i}, \ldots, Q 14.4_{i}, Q 15.1_{i}, \ldots, Q 15.14_{i}, Q 16_{i}\right) \\
S F_{i} \sim f\left(Q 10.1_{i}, \ldots, Q 10.17_{i}\right) \\
S C H_{i} \sim f\left(Q 9.1_{i}, \ldots, Q 9.10_{i}\right) \\
S M_{i} \sim f\left(Q 17.1_{i}, \ldots, Q 17.6_{i}\right) \\
C S R_{i} \sim f\left(S_{i}, E n v_{i}\right) \\
S o c_{i} \sim f\left(Q 11.1_{i}, \ldots, Q 11.10_{i}\right) \\
E n v_{i} \sim f\left(Q 11.11_{i}, \ldots, Q 11.22_{i}\right) \\
S C B_{i}=f\left(Q 3_{i}, Q 6_{i}, Q 7_{i}, Q 8_{i}, Q 18_{i}\right) \\
L G_{i}=f\left(S C H_{i}, C S R_{i}\right) \\
S F_{i}=f\left(C S R_{i}, S C H_{i}, S M_{i}, S C B_{i}\right) \\
S C H_{i}=f\left(S M_{i}, S C B_{i}\right)
\end{gathered}
$$

where Equations (1)-(8) represent the components (latent variables) assembled by confirmatory factor analysis (CFA), while Equations (9)-(11) capture the maximum log-likelihood regression fitted models. In addition, we assumed the existence of covariance between the following combinations of variables: slow fashion consumer behavior (SF) and luxury goods (LG), sustainable marketing (SM) and corporate social responsibility (CSR), and corporate social responsibility (CSR) and sustainable consumer habits (SCH). The statistical software R (v3.4.3) and its extension RStudio (v1.1.442) were used for calculation. 


\section{Results}

In designing the model, we assumed that 'sustainable consumer behavior' indirectly (through changes in 'sustainable consumer habits') affected the stimulation of luxury goods purchasing and directly affected 'slow fashion consumer behavior'. As the Cronbach's alpha for the given latent variable (SCB) was 0.105 (i.e., consistency was not demonstrated for any combination of variables pertaining to the concept of 'sustainable consumer habits'), we did not consider it in constructing the structural model. The consistency of the scale items belonging to the other latent variables is represented by Table 2 .

Table 2. Cronbach alpha for variables belonging to individual latent variables.

\begin{tabular}{lcc}
\hline \multirow{2}{*}{ Lat.var. } & \multicolumn{2}{c}{ Cronbach's Alpha } \\
\cline { 2 - 3 } & Generation Z & Generation $\mathbf{~}$ \\
\hline LG & 0.903 & 0.905 \\
SF & 0.909 & 0.912 \\
SCH & 0.870 & 0.889 \\
SM & 0.934 & 0.946 \\
Env & 0.973 & 0.970 \\
Soc & 0.958 & 0.957 \\
\hline
\end{tabular}

From the original model, the questions Q10.1 (I am willing to accept a higher price tag while buying fashion products?), Q14.1 (What is the highest price you are willing to pay for a luxury product? for clothing and footwear?), Q14.2 (What is the highest price you are willing to pay for a luxury product? for bags and accessories?), and Q14.3 (What is the highest price you are willing to pay for a luxury product? for cosmetics and fragrances?) were excluded from the model constructed for Generation Y. Although the variables achieved consistency with other variables in the conceptual framework, the model test statistics (Comparative Fit Index $=0.894$, Tucker-Lewis Index $=0.884$, and Model fit statistics $-\chi^{2}=2646.8$, where $p$-value $=0.041$ ) were inadequate/insufficient when incorporated. The structure of the assembled models for Generation $\mathrm{Y}$ and $\mathrm{Z}$ are shown in Figures A1 and A2 (in Appendix A), respectively; for clarity, 86 manifest variables are not displayed, only the latent variables are shown.

The arrows pointing from 'CSR' to the latent variables 'Soc' and 'Env' represent the relationships determined by factor analysis, where the dashed line indicates the factor to which the coefficient 1 was assigned. Values within the relationships represent a standardized factor loading. The rounded double-sided arrows (entering and exiting the same latent variable) represent the value of the variation. The two-sided straight arrows between the two latent variables capture the covariance and its value. The other (ordinary) arrows represent the dependence between the given latent variables and the value represents a standardized coefficient. The complete results for both models are shown in Tables 3 and 4 .

Table 3. Testing statistics of both constructed structural models.

\begin{tabular}{|c|c|c|c|c|c|c|}
\hline \multirow{5}{*}{ Gen. Z } & Model Fit Test Statistic & $\begin{array}{l}x^{2} \\
p \text {-value }\end{array}$ & $\begin{array}{l}3037.033 \\
{[0.726]}\end{array}$ & Model test baseline model & $\begin{array}{l}\chi^{2} \\
p \text {-value }\end{array}$ & $\begin{array}{c}3112.390 \\
{[0.658]}\end{array}$ \\
\hline & \multirow{2}{*}{$\begin{array}{l}\text { Standardized Root Mean } \\
\text { Square Residual }\end{array}$} & \multirow[t]{2}{*}{ SRSM } & \multirow[t]{2}{*}{0.043} & \multirow{2}{*}{$\begin{array}{l}\text { User model versus baseline } \\
\text { model }\end{array}$} & CFI & 0.935 \\
\hline & & & & & TLI & 0.929 \\
\hline & \multirow{2}{*}{$\begin{array}{l}\text { Root Mean Square Error of } \\
\text { Approximation }\end{array}$} & RMSEA & \multirow{2}{*}{\multicolumn{2}{|c|}{$\begin{array}{c}0.035 \\
{[0.000]}\end{array}$}} & $\mathrm{CI}$ & 0.033 \\
\hline & & $p$-value & & & $(90 \%)$ & 0.036 \\
\hline \multirow{6}{*}{ Gen. Y } & \multirow{2}{*}{ Model Fit Test Statistic } & $x^{2}$ & 2716.646 & \multirow{2}{*}{ Model test baseline model } & $x^{2}$ & 2792.570 \\
\hline & & $p$-value & [0.649] & & $p$-value & [0.597] \\
\hline & \multirow{2}{*}{$\begin{array}{l}\text { Standardized Root Mean } \\
\text { Square Residual }\end{array}$} & \multirow[t]{2}{*}{ SRSM } & \multirow[t]{2}{*}{0.048} & \multirow{2}{*}{$\begin{array}{l}\text { User model versus baseline } \\
\text { model }\end{array}$} & CFI & 0.902 \\
\hline & & & & & TLI & 0.893 \\
\hline & \multirow{2}{*}{$\begin{array}{l}\text { Root Mean Square Error of } \\
\text { Approximation }\end{array}$} & RMSEA & \multirow{2}{*}{\multicolumn{2}{|c|}{$\begin{array}{c}0.041 \\
{[0.000]}\end{array}$}} & CI & 0.040 \\
\hline & & $p$-value & & & $(90 \%)$ & 0.042 \\
\hline
\end{tabular}


Table 4. Results of both constructed structural models.

\begin{tabular}{|c|c|c|c|c|c|c|c|c|c|}
\hline \multicolumn{10}{|c|}{ Confirmatory factor analysis: } \\
\hline & & \multicolumn{4}{|c|}{ Generation Z } & \multicolumn{4}{|c|}{ Generation Y } \\
\hline Latent var. & Manifest var. & Estimate & Std. Err. & $\mathrm{P}(>|\mathrm{z}|)$ & Std. Est. & Estimate & Std. Err. & $\mathrm{P}(>|z|)$ & Std. Est. \\
\hline \multirow{2}{*}{$\frac{\widetilde{d}}{\tilde{d}}$} & Soc & 1.000 & & & 0.964 & 1.000 & & & 0.954 \\
\hline & Env & 1.159 & 0.056 & 0.000 & 0.934 & 1.173 & 0.100 & 0.000 & 0.917 \\
\hline \multirow{10}{*}{ 麦 } & Q11.1 & 1.000 & & & 0.833 & 1.000 & & & 0.794 \\
\hline & Q11.2 & 1.088 & 0.047 & 0.000 & 0.906 & 1.145 & 0.086 & 0.000 & 0.920 \\
\hline & Q11.3 & 0.959 & 0.062 & 0.000 & 0.691 & 1.005 & 0.114 & 0.000 & 0.678 \\
\hline & Q11.4 & 0.856 & 0.055 & 0.000 & 0.695 & 0.828 & 0.101 & 0.000 & 0.641 \\
\hline & Q11.5 & 1.121 & 0.045 & 0.000 & 0.932 & 1.119 & 0.081 & 0.000 & 0.940 \\
\hline & Q11.6 & 1.038 & 0.050 & 0.000 & 0.843 & 1.138 & 0.089 & 0.000 & 0.895 \\
\hline & Q11.7 & 1.070 & 0.049 & 0.000 & 0.873 & 1.159 & 0.088 & 0.000 & 0.913 \\
\hline & Q11.8 & 1.028 & 0.048 & 0.000 & 0.858 & 1.086 & 0.086 & 0.000 & 0.885 \\
\hline & Q11.9 & 1.058 & 0.050 & 0.000 & 0.856 & 1.104 & 0.088 & 0.000 & 0.881 \\
\hline & Q11.10 & 1.104 & 0.050 & 0.000 & 0.876 & 1.034 & 0.090 & 0.000 & 0.833 \\
\hline \multirow{12}{*}{ ஜூ } & Q11.11 & 1.000 & & & 0.946 & 1.000 & & & 0.967 \\
\hline & Q11.12 & 1.020 & 0.023 & 0.000 & 0.965 & 1.001 & 0.033 & 0.000 & 0.965 \\
\hline & Q11.13 & 1.007 & 0.024 & 0.000 & 0.958 & 1.007 & 0.033 & 0.000 & 0.965 \\
\hline & Q11.14 & 0.949 & 0.030 & 0.000 & 0.896 & 0.987 & 0.045 & 0.000 & 0.909 \\
\hline & Q11.15 & 0.989 & 0.026 & 0.000 & 0.938 & 0.967 & 0.047 & 0.000 & 0.891 \\
\hline & Q11.16 & 0.968 & 0.027 & 0.000 & 0.928 & 0.963 & 0.044 & 0.000 & 0.908 \\
\hline & Q11.17 & 0.652 & 0.043 & 0.000 & 0.633 & 0.617 & 0.084 & 0.000 & 0.536 \\
\hline & Q11.18 & 0.885 & 0.036 & 0.000 & 0.819 & 0.809 & 0.050 & 0.000 & 0.826 \\
\hline & Q11.19 & 0.870 & 0.036 & 0.000 & 0.818 & 0.882 & 0.048 & 0.000 & 0.864 \\
\hline & Q11.20 & 0.875 & 0.035 & 0.000 & 0.827 & 0.912 & 0.055 & 0.000 & 0.836 \\
\hline & Q11.21 & 0.854 & 0.037 & 0.000 & 0.795 & 0.854 & 0.059 & 0.000 & 0.793 \\
\hline & Q11.22 & 0.837 & 0.037 & 0.000 & 0.791 & 0.801 & 0.063 & 0.000 & 0.752 \\
\hline \multirow{6}{*}{$\sum_{\infty}$} & Q17.1 & 1.000 & & & 0.843 & 1.000 & & & 0.826 \\
\hline & Q17.2 & 0.982 & 0.045 & 0.000 & 0.871 & 1.121 & 0.082 & 0.000 & 0.899 \\
\hline & Q17.3 & 0.918 & 0.055 & 0.000 & 0.737 & 1.007 & 0.088 & 0.000 & 0.805 \\
\hline & Q17.4 & 1.009 & 0.045 & 0.000 & 0.883 & 1.082 & 0.080 & 0.000 & 0.890 \\
\hline & Q17.5 & 1.053 & 0.048 & 0.000 & 0.875 & 1.209 & 0.084 & 0.000 & 0.924 \\
\hline & Q17.6 & 0.982 & 0.049 & 0.000 & 0.830 & 1.086 & 0.089 & 0.000 & 0.839 \\
\hline \multirow{10}{*}{$\underset{W}{J}$} & Q9.1 & 1.000 & & & 0.320 & 1.000 & & & 0.421 \\
\hline & Q9.2 & 0.957 & 0.230 & 0.000 & 0.291 & 0.961 & 0.259 & 0.000 & 0.412 \\
\hline & Q9.3 & 2.488 & 0.420 & 0.000 & 0.732 & 1.418 & 0.297 & 0.000 & 0.686 \\
\hline & Q9.4 & 2.050 & 0.359 & 0.000 & 0.614 & 1.432 & 0.306 & 0.000 & 0.651 \\
\hline & Q9.5 & 2.210 & 0.383 & 0.000 & 0.644 & 1.698 & 0.344 & 0.000 & 0.757 \\
\hline & Q9.6 & 1.813 & 0.326 & 0.000 & 0.559 & 1.094 & 0.263 & 0.000 & 0.502 \\
\hline & Q9.7 & 2.157 & 0.367 & 0.000 & 0.704 & 1.614 & 0.323 & 0.000 & 0.781 \\
\hline & Q9.8 & 2.282 & 0.386 & 0.000 & 0.717 & 1.760 & 0.348 & 0.000 & 0.818 \\
\hline & Q9.9 & 2.576 & 0.431 & 0.000 & 0.762 & 1.646 & 0.329 & 0.000 & 0.786 \\
\hline & Q9.10 & 2.181 & 0.372 & 0.000 & 0.690 & 1.653 & 0.335 & 0.000 & 0.755 \\
\hline \multirow{10}{*}{ 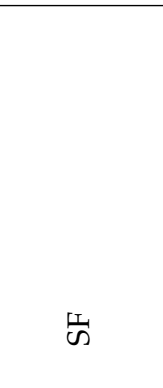 } & Q10.1 & 1.000 & & & 0.194 & & & & \\
\hline & Q10.2 & 2.985 & 0.823 & 0.000 & 0.715 & 1.000 & & & 0.735 \\
\hline & Q10.3 & 3.096 & 0.855 & 0.000 & 0.698 & 0.888 & 0.112 & 0.000 & 0.667 \\
\hline & Q10.4 & 3.349 & 0.925 & 0.000 & 0.698 & 1.253 & 0.126 & 0.000 & 0.820 \\
\hline & Q10.5 & 1.957 & 0.562 & 0.000 & 0.488 & 0.550 & 0.107 & 0.000 & 0.441 \\
\hline & Q10.6 & 3.783 & 1.043 & 0.000 & 0.720 & 1.224 & 0.131 & 0.000 & 0.776 \\
\hline & Q10.7 & 3.346 & 0.930 & 0.000 & 0.650 & 1.060 & 0.129 & 0.000 & 0.691 \\
\hline & Q10.8 & 2.962 & 0.827 & 0.000 & 0.621 & 0.850 & 0.126 & 0.000 & 0.571 \\
\hline & Q10.9 & 2.706 & 0.754 & 0.000 & 0.634 & 0.972 & 0.129 & 0.000 & 0.636 \\
\hline & Q10.10 & 3.520 & 0.969 & 0.000 & 0.736 & 1.200 & 0.126 & 0.000 & 0.792 \\
\hline
\end{tabular}


Table 4. Cont.

\begin{tabular}{|c|c|c|c|c|c|c|c|c|c|}
\hline & Q10.11 & 2.572 & 0.723 & 0.000 & 0.579 & 0.911 & 0.117 & 0.000 & 0.654 \\
\hline & Q10.12 & 1.732 & 0.502 & 0.001 & 0.460 & 0.412 & 0.096 & 0.000 & 0.369 \\
\hline & Q10.13 & 3.269 & 0.913 & 0.000 & 0.617 & 0.908 & 0.132 & 0.000 & 0.581 \\
\hline & Q10.14 & 3.457 & 0.951 & 0.000 & 0.742 & 1.269 & 0.124 & 0.000 & 0.842 \\
\hline & Q10.15 & 2.644 & 0.736 & 0.000 & 0.642 & 0.831 & 0.111 & 0.000 & 0.629 \\
\hline & Q10.16 & 2.588 & 0.741 & 0.000 & 0.496 & 0.881 & 0.139 & 0.000 & 0.537 \\
\hline & Q10.17 & 2.993 & 0.830 & 0.000 & 0.671 & 0.932 & 0.118 & 0.000 & 0.664 \\
\hline \multirow{24}{*}{$\underset{U}{U}$} & Q12 & 1.000 & & & 0.224 & 1.000 & & & 0.372 \\
\hline & Q13.1 & 1.530 & 0.490 & 0.002 & 0.236 & 1.802 & 0.500 & 0.000 & 0.451 \\
\hline & Q13.2 & 1.631 & 0.479 & 0.001 & 0.286 & 1.311 & 0.410 & 0.001 & 0.361 \\
\hline & Q13.3 & 1.918 & 0.561 & 0.001 & 0.288 & 1.431 & 0.479 & 0.003 & 0.324 \\
\hline & Q13.4 & 1.745 & 0.496 & 0.000 & 0.311 & 1.137 & 0.388 & 0.003 & 0.314 \\
\hline & Q14.1 & 1.300 & 0.378 & 0.001 & 0.293 & & & & \\
\hline & Q14.2 & 1.306 & 0.386 & 0.001 & 0.281 & & & & \\
\hline & Q14.3 & 0.332 & 0.133 & 0.012 & 0.162 & & & & \\
\hline & Q14.4 & 1.908 & 0.532 & 0.000 & 0.329 & 1.118 & 0.478 & 0.019 & 0.230 \\
\hline & Q15.1 & 4.094 & 0.991 & 0.000 & 0.628 & 3.381 & 0.771 & 0.000 & 0.784 \\
\hline & Q15.2 & 5.248 & 1.236 & 0.000 & 0.836 & 3.410 & 0.765 & 0.000 & 0.841 \\
\hline & Q15.3 & 4.154 & 0.996 & 0.000 & 0.686 & 2.592 & 0.635 & 0.000 & 0.610 \\
\hline & Q15.4 & 5.417 & 1.279 & 0.000 & 0.808 & 3.760 & 0.849 & 0.000 & 0.816 \\
\hline & Q15.5 & 4.668 & 1.108 & 0.000 & 0.758 & 3.078 & 0.719 & 0.000 & 0.713 \\
\hline & Q15.6 & 5.754 & 1.353 & 0.000 & 0.852 & 3.816 & 0.852 & 0.000 & 0.861 \\
\hline & Q15.7 & 3.927 & 0.964 & 0.000 & 0.565 & 2.519 & 0.654 & 0.000 & 0.522 \\
\hline & Q15.8 & 1.436 & 0.447 & 0.001 & 0.250 & 0.939 & 0.379 & 0.013 & 0.248 \\
\hline & Q15.9 & 4.666 & 1.117 & 0.000 & 0.694 & 3.291 & 0.758 & 0.000 & 0.751 \\
\hline & Q15.10 & 4.109 & 0.993 & 0.000 & 0.635 & 2.639 & 0.653 & 0.000 & 0.593 \\
\hline & Q15.11 & 4.855 & 1.155 & 0.000 & 0.742 & 2.969 & 0.695 & 0.000 & 0.708 \\
\hline & Q15.12 & 4.838 & 1.161 & 0.000 & 0.681 & 2.851 & 0.688 & 0.000 & 0.637 \\
\hline & Q15.13 & 3.438 & 0.873 & 0.000 & 0.468 & 2.907 & 0.726 & 0.000 & 0.577 \\
\hline & Q15.14 & 3.440 & 0.870 & 0.000 & 0.477 & 2.519 & 0.656 & 0.000 & 0.518 \\
\hline & Q16 & 1.852 & 0.573 & 0.001 & 0.254 & 1.589 & 0.506 & 0.002 & 0.350 \\
\hline \multicolumn{10}{|c|}{ Regressions: } \\
\hline & & \multicolumn{4}{|c|}{ Generation Z } & \multicolumn{4}{|c|}{ Generation Y } \\
\hline Dep.var. & Predictors & Estimate & Std. Err & $\mathrm{P}(>|\mathrm{z}|)$ & Std. all & Estimate & Std. Err & $\mathrm{P}(>|\mathrm{z}|)$ & Std. all \\
\hline \multirow{3}{*}{ LG } & CSR & 0.104 & 0.031 & 0.001 & 0.509 & 0.373 & 0.116 & 0.001 & 1.153 \\
\hline & $\mathrm{SCH}$ & 0.029 & 0.011 & 0.047 & 0.052 & -0.412 & 0.175 & 0.018 & -0.788 \\
\hline & CSR & 0.089 & 0.031 & 0.004 & 0.346 & 0.223 & 0.184 & 0.226 & 0.251 \\
\hline \multirow[t]{2}{*}{ SF } & $\mathrm{SCH}$ & 0.369 & 0.124 & 0.003 & 0.526 & 0.794 & 0.276 & 0.004 & 0.551 \\
\hline & $\mathrm{SM}$ & 0.015 & 0.016 & 0.347 & 0.058 & 0.121 & 0.083 & 0.146 & 0.147 \\
\hline $\mathrm{SCH}$ & SM & 0.262 & 0.045 & 0.000 & 0.726 & 0.381 & 0.084 & 0.000 & 0.668 \\
\hline \multicolumn{10}{|c|}{ Covariances: } \\
\hline & & \multicolumn{4}{|c|}{ Generation Z } & \multicolumn{4}{|c|}{ Generation Y } \\
\hline Var. & Var. & Estimate & Std. Err & $\mathrm{P}(>|\mathrm{z}|)$ & Std. all & Estimate & Std. Err & $\mathrm{P}(>|\mathrm{z}|)$ & Std. all \\
\hline CSR & SM & 0.571 & 0.056 & 0.000 & 0.808 & 0.571 & 0.093 & 0.000 & 0.819 \\
\hline SF & LG & 0.004 & 0.002 & 0.021 & 0.287 & 0.028 & 0.011 & 0.008 & 0.411 \\
\hline CSR & $\mathrm{SCH}$ & 0.053 & 0.012 & 0.000 & 0.303 & 0.139 & 0.035 & 0.000 & 0.471 \\
\hline
\end{tabular}

The results show the statistical significance of the perceived importance of applying CSR activities (by a company) in stimulating the purchase of luxury goods in both models (for Generation $Y$ and Generation Z). For Generation Y, this effect was stronger (more than twice as strong), mainly related to the negative impact of sustainable consumer habits (while, in the case of Generation $Z$, the slope is the opposite but insignificant). The results show that, within the model of Generation $Z$, the latent variables CSR and SCH were able to correspond to $30.3 \%$ of the variability within the constructed latent variable 'luxury goods purchasing'; in the model determining the internal relationships for Generation Y, it was 32.0\%. 
Based on the above, we can accept hypothesis H5 in both cases. Due to the opposite effects of SCH within the model of Generation Y, we cannot accept hypothesis H7 for that generation; however, it was accepted for the Generation $Z$. This means that sustainable consumer habits tend to lead to a decline in the purchase of luxury goods of Generation Y, which suggests that Generation Y does not consider luxury goods to be sustainable (they do not associate luxury goods with the concept of sustainability). Generation $\mathrm{Z}$ is indifferent when it comes to changing 'sustainable consumer habits' in terms of luxury brand purchases.

Furthermore, the impacts of three determinants- $\mathrm{CSR}, \mathrm{SCH}$, and $\mathrm{SM}-$ on the concept of slow fashion consumer behavior (SF) were analyzed. In the effect of the predictor SCH on slow fashion consumer behavior, disproportions were not found and significant results were recorded for both generations, with a similar relative effect strength determined by a standardized coefficient (Std. all). On this basis, it can be concluded that, when a consumer decides to improve their sustainable consumer habits, their tendency to apply slow fashion consumer behavior significantly increases (across both generations).

In the case of the remaining two predictors, differences between the generations were found. The perception of the importance of applying CSR has proved to be an important factor only in the case of a model built for the Generation $Z$, which its importance grew at the expense of the impact of $\mathrm{SM}$. The opposite trend was observed in Generation Y, where the growth of the relative strength of the (significant) latent SM variable led to an absence of the significance of CSR. The analyzed impact of the three predictors on generation $Z$ data accounted for $76.6 \%$ of the overall variability within the slow fashion variable; in the case of generation $Y$, this was up to $80.5 \%$ of the total variability.

Based on the results, it is possible to accept hypothesis $\mathrm{H} 8$ in both models (i.e., for both generations). Hypothesis H6 can be accepted only for the model of Generation Z and hypothesis H4 only for the model of Generation Y. The above-mentioned difference in the concept of sustainable marketing and application of CSR between generations $Z$ and $Y$ can be described as, in the case of the older generation, it was necessary to stimulate sustainable behavior whose level was not yet sufficient, which was reflected in the latent CSR variable. However, Generation Z's habits within sustainable behavior (and, hence, sustainable consumption) are well developed, leading to a loss of importance (and success) in sustainable marketing, while socially responsible entrepreneurship became an important factor for that generation.

We also identified the indirect influence of the latent variable $\mathrm{SM}$ on the stimulation of purchases of luxury goods (influenced by changes in $\mathrm{SCH}$ ). The model demonstrated a directly proportional and statistically significant dependence of changes in consumer behavior on the basis of SM, with the relative strength of the effect being similar in both cases. Based on these findings, we can accept both hypotheses concerning a latent variable advocating the importance of applying sustainable marketing. The relationship explained $52.7 \%$ variability of the dependent variable in generation $\mathrm{Z}$ and $44.7 \%$ in generation Y. This finding is in agreement with the lack of significance of SM on changes in slow fashion consumer behavior. As it was not possible to consider a latent variable representing sustainable consumer behavior (SCB), hypotheses $\mathrm{H} 1$ and $\mathrm{H} 2$ could not be accepted or rejected. The results also confirmed the hypothesis of a positive (and directly proportional) relationship between two combinations of variables; namely, between slow fashion consumer behavior and the stimulation of luxury goods purchase (hypothesis H10), and between the application of CSR and SCH (hypothesis H9). The results of the hypothesis testing are summarized in Table 5. 
Table 5. Results of hypothesis testing.

\begin{tabular}{cl}
\hline Hypothesis & \multicolumn{1}{c}{ Verification of Hypothesis } \\
\hline H1 & Neither confirmed nor rejected \\
H2 & Neither confirmed nor rejected \\
H3 & Accepted for both examined generations (Generation Y and Z) \\
H4 & Rejected \\
H5 & Accepted for both examined generations (Generation Y and Z) \\
H6 & Accepted for Generation Z \\
H7 & Accepted for Generation Z \\
H8 & Accepted for both examined generations (Generation Y and Z) \\
H9 & Accepted for both examined generations (Generation Y and Z) \\
H10 & Accepted for both examined generations (Generation Y and Z) \\
\hline
\end{tabular}

\section{Generational Differences in Manifest Variables}

In this section, we focus on the aspects of Italian consumer perception and behavior which presented the most significant differences between the two examined generations.

Regarding sustainable consumer habits, the most significant inter-generational differences were found in following areas: (1) tendency to buy clothes from second-hand stores (Generation Y bought more often); (2) tendency to buy clothes from vintage stores (Generation Y bought more often); (3) tendency to eat organic products (stronger tendency in Generation Y); and (4) preference to buy clothing made from recycled materials (stronger preference in Generation Y).

Out of 17 questions about slow fashion consumer behavior, the most significant differences were found in the following questions: (1) interest in transparent communication of the brand (Generation $\mathrm{Y}$ was more interested in this aspect); (2) the importance of personalized service when purchasing (more important for Generation Y); (3) the perception of Slow Fashion is a "competitor" of Fast Fashion (Generation $Z$ was more inclined towards this view); and (4) perceived importance of the support of local community by fashion brand/company (more important for Generation Y).

Štefko and Steffek's [25] Fashion-Matrix-based framework for positioning the Slow Fashion movement within the industry-specific fashion segments identified eight factors that determine each fashion segment and provide a qualitative overview of their traits. In the upper segment of the matrix, they positioned Haute Couture, along with one-of-a-kind and artistic collections (Prêt-à-couture and Prêt-à-porter), which represent the aspects of luxury fashion. The reason for this division is rooted in the fact that most eminent existing fashion players have neither explicitly adopted nor rejected the novel concept of Slow Fashion. Following this study, our goal was to reveal whether slow fashion-oriented consumers are also luxury fashion consumers. If we can consider luxury fashion as a fashion featuring aspects of slow fashion, from the perspective of the generations examined we can admit this statement.

Concerning slow fashion consumer behavior, we also investigated whether the respondents were willing to accept a higher price for sustainable products. The results of our research show that the majority of respondents were willing to pay a $20 \%$ increase in price in order to buy a product made and offered on the market by a sustainable fashion brand. Previous studies have revealed similar consumer trends. For example, Ciasullo et al. [53] found that consumers claimed to be absolutely committed to promoting environmental protection by means of making purchasing choices more focused on the adoption of sustainable practices. In addition, comparison of our findings with those of Sullivan [43] revealed some differences: we found that Millennials were not willing to pay more for sustainable products (unlike Generation Z).

We examined respondent's views on CSR through 22 questions, divided into environmental and social aspects. There were no significant intergenerational differences in these items, except for one item in the social area ("For me, it is important that the brand I buy and wear offers key positions to long-term employees").

In the questions focused on (purchasing) luxury y goods, differences were found in (1) frequency of purchasing (Generation Y purchased luxury products more often); (2) type of purchased products 
(Generation Y bought more clothing, footwear, bags, and accessories); (3) functions/attributes that give rise to a purchase ("added value" as well as "reflection of social status" were more common among the responses of Generation Y); and (4) the frequency of following luxury brand profiles on social networks (higher for Millennials).

\section{Discussion and Conclusions}

Italian consumers from Generation $Y$ were found to have better sustainable consumer habits than those of Generation Z, as, in all four items (out of a total of 11 items) in which significant generational differences were found, Millennials had better scores. Millennials were also more interested in transparent communication of the brand, which was consistent with other findings: transparent brand communication is an element of CSR activities and the analysis of relationship between latent variables shows that, when buying luxury goods, CSR activities of the brand were more important for Generation Y. Generation $Y$ favored personalized services, which is not only an attribute of slow fashion consumer behavior, but also one of the main aspects of luxury goods marketing. As research has revealed that Generation Y purchases luxury goods more often (in order to show their social status), it can be stated that this generational cohort favors luxury brands that have a more personal approach to the customer. Generation $Z$ regards slow fashion as a competitor to Fast fashion, which can also be determined by the relationship between the latent variables: Generation $Z$ was more slow fashion-oriented than generation $Y$. This may also be related to the relationship between the latent variables, in that it was less important for Generation Y that luxury goods had slow fashion attributes. It is likely that Generation $Y$ still considers luxury goods to be fast fashion. For Millennials, it was (more) important that the fashion brand/company supports local communities; this may be related to the life cycle phase, Generation $Y$ is older and more likely to be interested in starting a family and settling down, therefore realizing the need for a strong community.

Examination of the relationships between the latent variables has shown, inter alia, that CSR had a statistically significant positive impact on the purchase of luxury goods for both generations (H5). For Generation Y, the perception of applying CSR activities (std. all at 1.153) was more important than for Generation Z (std. all at 0.509). Regarding the impact of sustainable consumer habits on the purchase of luxury goods, differences were found between the two generations. For Generation $Y$, the variables tended to have the opposite tendency; that is, the more luxury goods a consumer buys, the less sustainable consumer habits he/she applies. On the contrary, the sustainable consumer habits of Generation Z (std. all at 0.052 level) had a positive impact on its purchase of luxury products: as $\mathrm{SCH}$ increases, so does the purchase of luxury products.

If we consider the perception of the need for CSR activities to be implemented by brands as a prerequisite for slow fashion consumer behavior, then it can be stated that the more important it is for consumers that the brand (they buy and wear) is active in CSR, the more they are oriented towards slow fashion consumer behavior.

Sustainable marketing did not directly affect consumer orientation to slow fashion (H4), but affected the change in sustainable consumer habits, which has an indirect impact on the consumption of luxury products (H3); for Generation Z, this effect was stronger, but it was confirmed for both generations. On this basis, we argue that strengthening sustainable marketing activities for luxury brands will have an impact on their consumer growth.

The study presented here examined consumer perceptions of CSR activities of companies and the impact of CSR activities on customer purchase intentions. The results show a different perception of sustainability by consumers of Generations $\mathrm{Y}$ and Z. There was prevailing tendency of Millennials to perceive sustainability and involvement in CSR activities as a modern trend which is currently on the rise and to behave accordingly. This implies a recommendation to strengthen sustainable marketing for luxury brands, focusing in particular on Generation Y. The impact of the perception of CSR activities on the slow fashion preference was higher for the Generation Z, meaning that Generation Z (std. all at the level of 0.346) perceived CSR activities as a more important factor in brand selection. From a 
managerial point of view, this study shows that luxury brands must pay more attention to the issues of sustainability and CSR, to which young Italian consumers are particularly sensitive. The research also highlights the importance of adopting differentiated sustainable marketing strategies based on the characteristics of the target generations, favoring value propositions guided by slow fashion principles for Generation Z.

Like other studies, this study had some limitations, of which the most significant was the fact that the survey was conducted in a single geographical area (the sample was limited to Italian consumers). It is desirable and would be beneficial for future research to focus on a wider sample of respondents and to carry out comparative analyses between young consumers from different geographical areas, at both a European and a global level. We believe that cross-cultural research will contribute to a better understanding of different viewpoints and perceptions regarding luxury and sustainable brands. Future research may also focus on investigating whether the specific CSR initiatives of luxury brands are effective.

Author Contributions: Conceptualization, T.P., V.A.T., and V.Š.; methodology, T.P. and V.Š.; software and validation, T.V.; formal analysis, T.V.; investigation, T.P. and V.Š.; resources, V.A.T.; data curation, T.P. and V.Š.; writing — original draft preparation, review and editing, V.A.T.; visualization, V.A.T.; supervision, T.P.; project administration and funding acquisition, R.F. All authors have read and agreed to the published version of the manuscript.

Funding: This research was funded by Vedecká Grantová Agentúra MŠVVaŠ SR a SAV (VEGA).

Acknowledgments: This research is one of the partial outputs under the scientific research grants VEGA 1/0789/17 "Research of e-commerce with relation to dominant marketing practices and important characteristics of consumer behavior while using mobile device platforms" and VEGA 1/0609/19 "Research on the development of electronic and mobile commerce in the aspect of the impact of modern technologies and mobile communication platforms on consumer behavior and consumer preferences".

Conflicts of Interest: The authors declare no conflict of interest. 
Appendix A

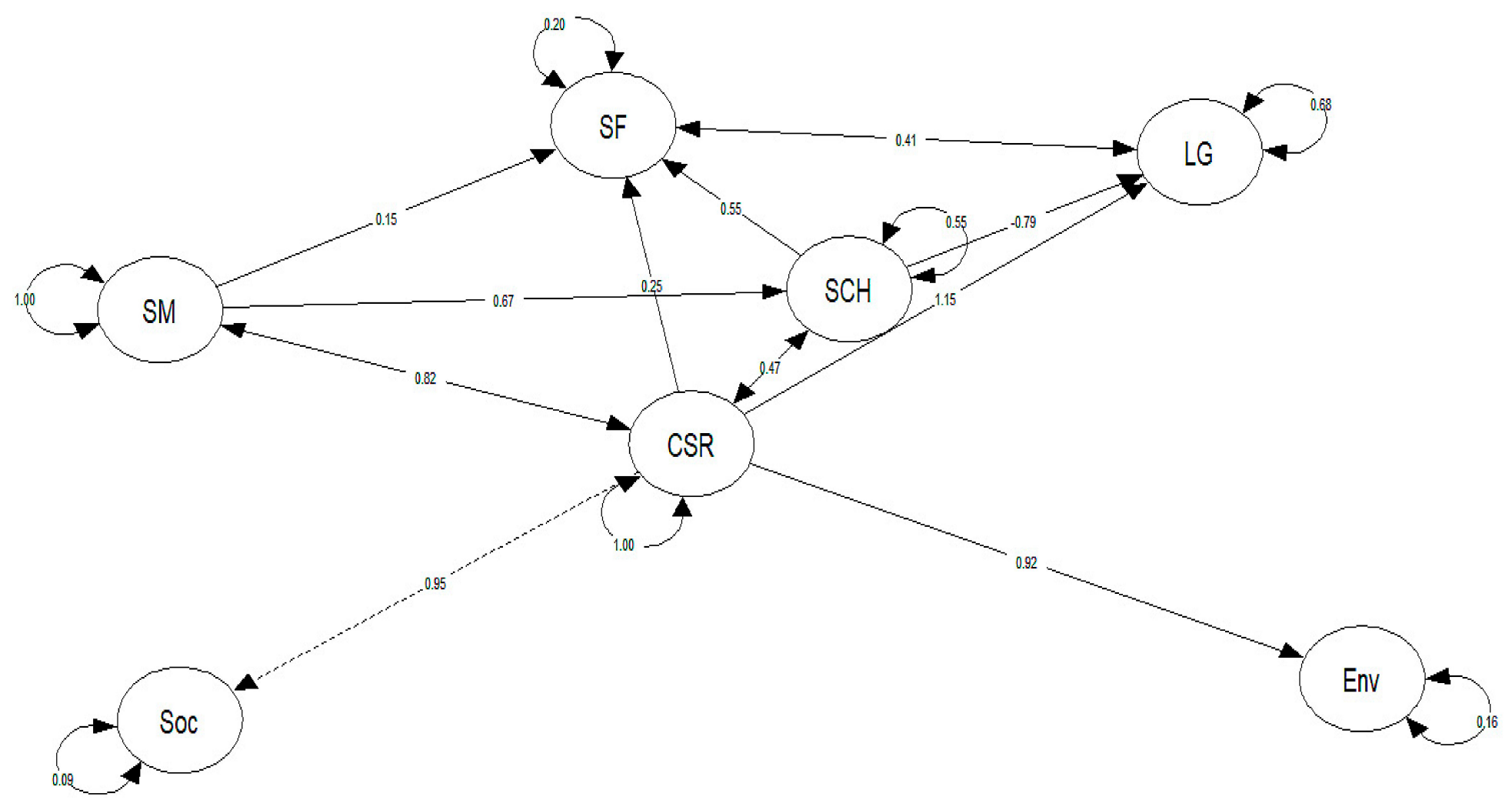

Figure A1. Structural equation model for generation Y. 


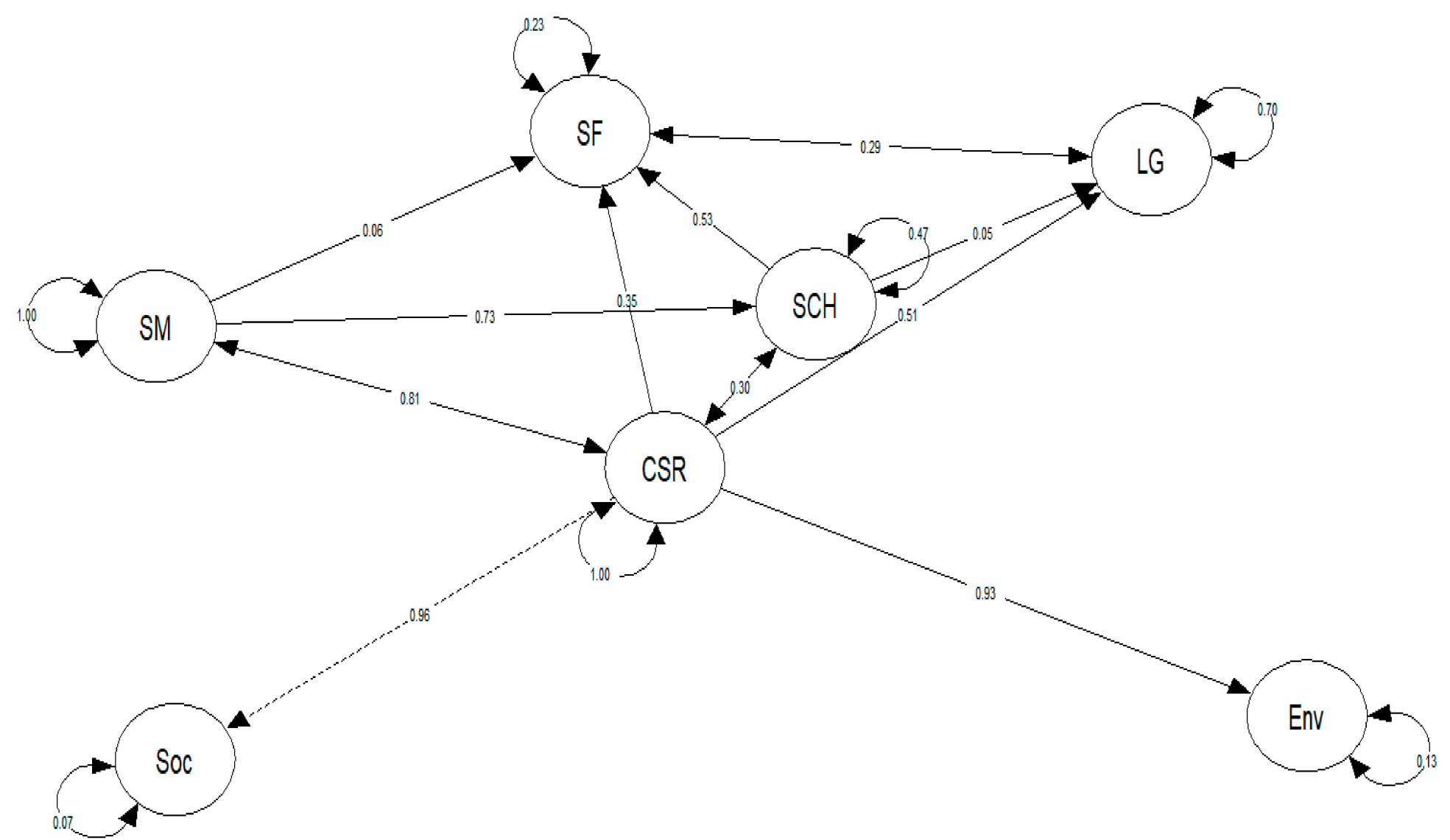

Figure A2. Structural equation model for generation Z. 


\section{References}

1. Hauck, W.E.; Stanforth, N. Cohort perception of luxury goods and services. J. Fash. Mark. Manag. 2007, 11, 175-188. [CrossRef]

2. Rolling, V.; Sadachar, A. Are sustainable luxury goods a paradox for millennials? Soc. Responsib. J. 2017, 14, 802-815. [CrossRef]

3. Costa Pinto, D.; Maurer Herter, M.; Gonçalves, D.; Sayin, E. Can luxury brands be ethical? Reducing the sophistication liability of luxury brands. J. Clean. Prod. 2019, 233, 366-1376. [CrossRef]

4. Stępień, B. Snobbish bandwagoners: Ambiguity of luxury goods' perception. J. Manag. Bus. Adm. Cent. Eur. 2018, 26, 79-99. [CrossRef]

5. Dubois, B.; Laurent, G.; Czellar, S. Consumer Rapport to Luxury: Analyzing Complex and Ambivalent Attitudes; HEC Research Papers Series 736; HEC Paris: Jouy-en-Josas, France, 2001.

6. Kapferer, J.N.; Bastien, V. The specificity of luxury management: Turning marketing upside down. J. Brand Manag. 2009, 16, 311-322. [CrossRef]

7. Chevalier, M.; Gutsatz, M. Luxury Retail Management: How the World's Top Brands Provide Quality Product and Service Support; John Wiley \& Sons: Singapore, 2012.

8. Berry, C.J. The Idea of Luxury: A Conceptual and Historical Investigation; Cambridge University Press: Cambridge, UK, 1994.

9. Jackson, T.B. International Retail Marketing; Elsevier Butterworth-Heinemann: Oxford, UK, 2004.

10. Fionda, A.M.; Moorey, C. The anatomy of the luxury fashion brand. J. Brand Manag. 2009, 16, $347-363$. [CrossRef]

11. Phau, I.; Prendergast, G. Consuming luxury brands: The relevance of the 'Rarity Principle'. J. Brand Manag. 2000, 8, 122-138. [CrossRef]

12. Godey, B.; Pederzoli, D.; Aiello, G.; Donvito, R.; Chan, P.; Tsuchiya, J.; Ivanovna, I.; Skorobogatykh, W.B.; Oh, H.; Singh, R. Modeling links between decision-making process and luxury brand attachment: An international comparison. J. Glob. Sch. Mark. Sci. 2013, 23, 361-378. [CrossRef]

13. Koehn, N.F. Brand New: How Entrepreneurs Earned Consumers' Trust from Wedgwood to Dell; Harvard Business School Press: Boston, MA, USA, 2001.

14. Kim, A.J.; Ko, E. Impacts of Luxury Fashion Brand's Social Media Marketing on Customer Relationship and Purchase Intention. J. Glob. Fash. Mark. 2010, 1, 164-171. [CrossRef]

15. Chow, P.S.; Li, C.K.Y. Towards Closed-Loop Fashion Supply Chains-Reflections from Retailer-Facilitated Used Apparel Collection Programs. In Contemporary Case Studies on Fashion Production, Marketing and Operations; Springer Series in Fashion Business; Springer Nature: Singapore, 2018.

16. Yang, S.; Song, Y.; Tong, S. Sustainable Retailing in the Fashion Industry: A Systematic Literature Review. Sustainability 2017, 9, 1266. [CrossRef]

17. Woodside, A.G.; Fine, M.B. Sustainable fashion themes in luxury brand storytelling: The sustainability fashion research grid. J. Glob. Fash. Mark. 2019, 10, 111-128. [CrossRef]

18. Lundblad, L.; Davies, I.A. The values and motivations behind sustainable fashion consumption. J. Consum. Behav. 2016, 15, 149-162. [CrossRef]

19. Han, J.; Seo, Y.; Ko, E. Staging luxury experiences for understanding sustainable fashion consumption: A balance theory application. J. Bus. Res. 2017, 74, 162-167. [CrossRef]

20. Jawahir, I.S.; Dillon, O.W.; Rouch, K.E.; Joshi, K.J.; Venkatachalam, A.; Jaafar, I.H. Total life-cycle considerations in product design for sustainability: A framework for comprehensive evaluation. In Proceedings of the 10th International Research/Expert Conference "Trends in the Development of Machinery and Associated Technology", TMT 2006, Lloret de Mar, Spain, 11-15 September 2006.

21. Brady, K. What makes a sustainable product? Available online: https://www.greenbiz.com/article/whatmakes-sustainable-product-0. (accessed on 27 November 2018).

22. Hosseinpour, M.; Nezakati, H.; Md Sidin, S.; Yee, W.F. Consumer's Intention of Purchase Sustainable Products: The Moderating Role of Attitude and Trust (conference paper). In Proceedings of the 8th Annual International Business, Agriculture, Health, Energy, \& Engineering Conference (IBAHEEC2015), Los Angeles, CA, USA, 27-28 December 2015.

23. Pui-Yan Ho, H.; Choi, T.M. A Five-R analysis for sustainable fashion supply chain management in Hong Kong: A case analysis. J. Fash. Mark. Manag. 2012, 16, 161-175. [CrossRef] 
24. NCGreenpower. Sustainable fashion: Part 2- Upcycle Your Clothes. Available online: https://www. ncgreenpower.org/sustainable-fashion-upcylce-clothes/ (accessed on 15 December 2018).

25. Štefko, R.; Steffek, V. Key Issues in Slow Fashion: Current Challenges and Future Perspectives. Sustainability 2018, 10, 2270. [CrossRef]

26. Fletcher, K. Slow Fashion: An Invitation for Systems Change. Fash. Pract. 2010, 2, 259-265. [CrossRef]

27. McKeown, C.; Shearer, L. Taking sustainable fashion mainstream: Social media and the institutional celebrity entrepreneur. J. Consum. Behav. 2019, 18, 406-414. [CrossRef]

28. Cavender, R. The Marketing of Sustainability and CSR Initiatives by Luxury Brands: Cultural Indicators, Call to Action, and Framework. In Sustainability in Luxury Fashion Business; Springer-Verlag Singapore PTE Ltd.: Singapore, 2018; pp. 29-49.

29. Tsai, W.H.S.; Men, L.R. Motivations and antecedents of consumer engagement with brand pages on social networking sites. J. Interact. Advert. 2013, 13, 76-87. [CrossRef]

30. Jin, A.S. The potential of social media for luxury brand management. Mark. Intell. Plan. 2012, 30, 687-699.

31. Godey, B.; Manthiou, A.; Pederzoli, D.; Rokka, J.; Aiello, G.; Donvito, R.; Singh, R. Social media marketing efforts of luxury brands: Influence on brand equity and consumer behavior. J. Bus. Res. 2016, 69, 5833-5841. [CrossRef]

32. Deloitte. Global Powers of Luxury Goods 2019 - Bridging the Gap between the Old and the New. Available online: https://www2.deloitte.com/content/dam/Deloitte/ar/Documents/Consumer_and_ Industrial_Products/Global-Powers-of-Luxury-Goods-abril-2019.pdf (accessed on 27 December 2019).

33. Carrigan, M.; Moraes, C.; McEachern, M. From conspicuous to considered fashion: A harm-chain approach to the responsibilities of luxury-fashion businesses. J. Mark. Manag. 2013, 29, 1277-1307. [CrossRef]

34. Amatulli, C.; De Angelis, M.; Korschun, D.; Romani, S. Consumers' perceptions of luxury brands' CSR initiatives: An investigation of the role of status and conspicuous consumption. J. Clean. Prod. 2018, 194, 277-287. [CrossRef]

35. Joo, S.; Miller, E.G.; Fink, J.S. Consumer evaluations of CSR authenticity: Development and validation of a multidimensional CSR authenticity scale. J. Bus. Res. 2019, 98, 236-249. [CrossRef]

36. Bednárová, L.; Chovancová, J.; Sirková, M. Medzinárodný manažment; Bookman, s.r.o.: Prešov, Slovakia, 2012.

37. Pencarelli, T.; Ali Taha, V.; Škerháková, V.; Valentiny, T. Generational differences in CSR perception: focusing on Italian e-commerce market. In Management 2018: Management and the World in Motion, Challenges, Opportunities and Threats; Bookman sro for University of presov: Prešov, Slovakia, 2018.

38. Sojka, L.; Tej, J. Manažment - vybrané state a aplikácie; Bookman, s.r.o.: Prešov, Slovakia, 2019.

39. Shnayder, L.; van Rijnsoever, F.J.; Hekkert, M.P. Putting Your Money Where Your Mouth Is: Why Sustainability Reporting Based on the Triple Bottom Line Can Be Misleading. PLoS ONE 2015, 10, e0119036. [CrossRef]

40. Godart, F.; Seong, S. Is sustainable luxury fashion possible? In Sustainable Luxury: Managing Social and Environmental Performance in Iconic Brands; Routledge: Abingdon-on-Thames, UK, 2014.

41. Arrigo, E. Corporate Sustainability in Fashion and Luxury Companies. Symph. Emerg. Issues Manag. 2015, 4, 9-23.

42. Bianchi, A. I Millennial Italiani in 5 punti. Available online: http://www.ninjamarketing.it/2016/09/29/imillennial-italiani-in-5-punti/ (accessed on 15 April 2018).

43. Sullivan, P. Corporate Social Responsibility. Available online: http://www.thenonprofittimes.com/newsarticles/corporate-social-responsibility/ (accessed on 12 May 2019).

44. Bolton, R.N. Understanding Generation $Y$ and their use of social media: a review and research agenda. J. Serv. Manag. 2013, 24, 245-267. [CrossRef]

45. Korzeniowska, A. Generation Y on the e-commerce market. Comparison between Polish and South Korean young consumers behaviour. J. Mark. Consum. Behav. Emerg. Mark. 2015, 2, 33-48. [CrossRef]

46. Brandon, A. CSR and Millennials: Corporate Social Responsibility Matters to This Group. Available online: https://www.franchising.com/articles/csr_and_millennials_corporate_social_responsibility_matters_ to_this_group.html (accessed on 12 May 2019).

47. Dara, V. Generazione Z: così i marketer scoprono un nuovo target "d'oro". Available online: https: //www.insidemarketing.it/generazione-z-marketer-target-doro/ (accessed on 25 April 2018).

48. Coni, R. Generazione Z: le caratteristiche del target. Available online: https://www.tsw.it/digital-marketing/ generazione-z-le-caratteristiche-del-target/ (accessed on 25 April 2018). 
49. Uche, S. Generation Z and Corporate Social Responsibility; Syracuse University: Syracuse, NY, USA, 2018; p. 226. Available online: https://surface.syr.edu/thesis/226 (accessed on 27 December 2019).

50. Arıker, Ç.; Toksoy, A. Generation Z and CSR: Antecedents Of purchasing intention of university students. Kafkas Üniversity Fac. Econ. Adm. Sci. J. 2017, 8, 483-502. [CrossRef]

51. Franzen, A.; Vogl, D. Two Decades of Measuring Environmental Attitudes: A Comparative Analysis of 33 Countries. Glob. Environ. Chang. 2013, 23, 1001-1008. [CrossRef]

52. Milfont, T.L.; Markowitz, E. Sustainable consumer behavior: A multilevel perspective. Curr. Opin. Psychol. 2016, 10, 112-117. [CrossRef]

53. Ciasullo, M.V.; Maione, G.; Torre, C.; Troisi, O. What about Sustainability? An Empirical Analysis of Consumers' Purchasing Behavior in Fashion Context. Sustainability 2017, 9, 1617. [CrossRef]

(C) 2019 by the authors. Licensee MDPI, Basel, Switzerland. This article is an open access article distributed under the terms and conditions of the Creative Commons Attribution (CC BY) license (http://creativecommons.org/licenses/by/4.0/). 